九州大学学術情報リポジトリ

Kyushu University Institutional Repository

\title{
Biological Characteristics and Cultivation of Fruit Body of Wild Edible Mushroom Auricularia villosula
}

ZHANG, Yu Xiao

Institute of Mycology/Engineering Research Center of Chinese Ministry of Education for Edible and Medicinal Fungi, Jilin Agricultural University

BAU, Tolgor

Institute of Mycology/Engineering Research Center of Chinese Ministry of Education for Edible and Medicinal Fungi, Jilin Agricultural University

OHGA, Shoji

Institute of Mycology/Engineering Research Center of Chinese Ministry of Education for Edible and Medicinal Fungi, Jilin Agricultural University | Department of Agro-environmental

Sciences, Faculty of Agriculture, Kyushu University

https://doi.org/10.5109/1909896

出版情報: 九州大学大学院農学研究院紀要. 63 (1)，pp.5-14，2018-02-27. Faculty of Agriculture， Kyushu University

バージョン：

権利関係 : 


\title{
Biological Characteristics and Cultivation of Fruit Body of Wild Edible Mushroom Auricularia villosula
}

\author{
Xiao Yu ZHANG ${ }^{1}$, Tolgor BAU ${ }^{1 *}$ and Shoji OHGA ${ }^{1,2 *}$ \\ ${ }^{1}$ Institute of Mycology/Engineering Research Center of Chinese Ministry of Education for Edible and \\ Medicinal Fungi, Jilin Agricultural University, Changchun 130118, P. R. China \\ ${ }^{2}$ Department of Agro-environmental Sciences, Faculty of Agriculture, \\ Kyushu University, Sasaguri, Fukuoka 811-2415, Japan \\ (Received September 16, 2017 and accepted November 20, 2017)
}

\begin{abstract}
A special specimen was discovered in Erdos of China, which grown on Artemisia ordosica. It is identified as Auricularia villosula Malysheva, based on morphological characteristics and polygenic analysis. This is the first time we discovered this species grows on subshrub. Addition, the study of biological characteristics and cultivation has been done for the first time for this species.

For the screening of single optimal factor, each of 3 inorganic salt concentration on from $0.5 \%$ to $1.5 \%$ at $0.5 \%$ interval, each of 8 carbon sources and nitrogen sources and each of 10 growth factors were tested for the mycelia growth rate and mycelia growth potential. As a result, the fungus grew better on maltose, sucrose, fructose as the carbon sources; soybean flour, yeast extract, wheat bran as the nitrogen sources; mushrooms, bean sprouts, potatoes as growth factors and $0.5 \% \mathrm{~K}^{+}, 0.5 \% \mathrm{PO}_{4}^{3-}, 1 \% \mathrm{Mg}^{2+}$. The orthogonal experiments with the above selected three conditions for each of the four factors were then performed and the optimal cultivation conditions were determined. A descending order of the impact for the four factors was growth factors $>$ carbon source $>$ inorganic salt concentration on $>$ nitrogen source and the F-test showed very significant difference among all the four factors. The optimal culture condition for $A$. villosula was the combination of potato juice plus sucrose, soybean powder and $0.5 \% \mathrm{PO}_{4}{ }^{3-}$. Based on the results of orthogonal, temperatures from $15^{\circ} \mathrm{C}$ to $35^{\circ} \mathrm{C}$ at $5^{\circ} \mathrm{C}$ interval, $\mathrm{pH}$ at 4 to 8 at 1 interval, as a result, the fungus grew better on $30^{\circ} \mathrm{C}$ and $\mathrm{pH} 8$.

In the domestication experiments of $A$. villosula, the stages of pre-culture spawn, of manufacturing cultural bags, of spawn running, of inducement to primordium, of fruiting period management, of collected periods were studied. The cultivated fruiting bodies showed the appearance identical to the wild ones under optimal conditions.
\end{abstract}

Key words: biological characteristics, single factor, orthogonal test, domesticated

\section{INTRODUCTION}

Auricularia Bull. is a genus in Agaricales Underw (Bulliard 1780), containing 27 species known worldwide, and 15 species were recorded from China (Wu, 2016). Taxonomist attempted to distinguish the species based on the features, such as color, hair length, characteristic of medulla and spores (Lowy, 1952; Kobayasi, 1981; LI Lijia, 1984). However, due to theslightly different between some species and its related, it is considered difficult to be identified. In recently, molecular analysis of sequences, such as ITS, LSU, tef-1, RPB2 et al., was widespread used in taxonomy, which makes great contribution to divide different species. (Bandara, 2005; Fan et al., 2014; Matheny et al., 2007; Malysheva \& Bulakh, 2014; Yang et al., 2010; Yan et al., 1999; Wu et al., 2014). It also promotes the study of Auricularia.

The Auricularia is well known in Eastation due to its edible and medicinal properties. Auricularia heimuer and Auricularia conera has been widely cultivated and

${ }^{1}$ Institute of Mycology/Engineering Research Center of Chinese Ministry of Education for Edible and Medicinal Fungi, Jilin Agricultural University, Changchun 130118, P. R. China

${ }^{2}$ Department of Agro-environmental Sciences, Faculty of Agriculture, Kyushu University, Sasaguri, Fukuoka 811-2415, Japan

* Corresponding authors (E-mail: ohga@forest.kyushu-u.ac.jp, junwusuo@126.com) become a feast on the table. Auricularia villosula is also eaten and very popular in Erdos city, Inner Mongolia Autonomous Region, China. But the biological and cultivation Characteristics is not reported. So, this paper conducted a study deep step.

Auricularia villosula Malysheva was described from Russian Far East by Malysheva in 2014, which grown on wood of deciduous trees. In our study, we discovered a special specimen, very similar to A. villosula, but with medulla and grown on Artemisia ordosica Krasch. (subshrub). So some question emerged. What is this specimen? And What biological characteristics and cultivation Characteristics is? This also the major study in this paper.

\section{MATERIALS AND METHODS}

\section{Morphological studies}

Specimens were collected from Erdos city, Inner Mongolia Autonomous Region, China. They were dried by hot air oven at $40^{\circ} \mathrm{C}$ and preserved in the Herbarium Mycology of Jilin Agriculture University (HMJAU), HMJAU37794. Descriptions of species are according to Wu et al. (2014). The strain was originally isolated from the fruit body, and deposited in strains library of fungi diversity laboratory which are attached to engineering research center of Chinese ministry of education for edible and medicinal fungi in Jilin agricultural university, 
Table 1. List of species, specimes and locality accession number of sequences used in this study

\begin{tabular}{|c|c|c|c|c|c|c|}
\hline No & Species & Specimen No. & $\begin{array}{l}\text { GenBank } \\
\text { ITS }\end{array}$ & $\begin{array}{l}\text { GenBank } \\
\text { LSU }\end{array}$ & $\begin{array}{l}\text { GenBank } \\
\text { RPB2 }\end{array}$ & Country \\
\hline 1 & $\begin{array}{l}\text { Auricularia } \\
\text { villosula }\end{array}$ & HMJAU37794 & •* & • & $\bullet$ & $\begin{array}{l}\text { Erdos City, Inner Mongolia } \\
\text { Autonomous Region, China }\end{array}$ \\
\hline 2 & $\begin{array}{l}\text { Auricularia } \\
\text { villosula }\end{array}$ & VLA M-11291 & KJ698417 & - & KJ698440 & Russia, Far East \\
\hline 3 & $\begin{array}{l}\text { Auricularia } \\
\text { villosula }\end{array}$ & LE296422 & KJ698418 & - & KJ698441 & Russia, Far East \\
\hline 4 & $\begin{array}{l}\text { Auricularia } \\
\text { villosula }\end{array}$ & HMJAU2931 & $\bullet$ & - & $\bullet$ & Russia, Far East \\
\hline 5 & $\begin{array}{l}\text { Auricularia } \\
\text { heimuer }\end{array}$ & HMJAU7931 & $\bullet$ & • & • & $\begin{array}{l}\text { Aershan City, Inner Mongolia } \\
\text { Autonomous Region, China }\end{array}$ \\
\hline 6 & $\begin{array}{l}\text { Auricularia } \\
\text { delicata }\end{array}$ & HMJAU2316 & $\bullet$ & • & $\bullet$ & $\begin{array}{c}\text { Xishuangbanna City, Yunnan } \\
\text { Province, China }\end{array}$ \\
\hline 7 & $\begin{array}{l}\text { Auricularia } \\
\text { orientalis }\end{array}$ & HMJAU6055 & $\bullet$ & • & $\bullet$ & $\begin{array}{l}\text { Tongliao City, Inner Mongolia } \\
\text { Autonomous Region, China }\end{array}$ \\
\hline 8 & $\begin{array}{l}\text { Auricularia } \\
\text { americana }\end{array}$ & HMJAU21889 & • & $\bullet$ & • & $\begin{array}{c}\text { Dunhua City, Jilin Province, } \\
\text { China }\end{array}$ \\
\hline 9 & $\begin{array}{l}\text { Auricularia } \\
\text { heimuer }\end{array}$ & Dai 13503 & KM396789 & KM396840 & KP729316 & $\begin{array}{c}\text { Mudanjiang City, Heilongjiang } \\
\text { Province, China }\end{array}$ \\
\hline 10 & $\begin{array}{l}\text { Auricularia } \\
\text { heimuer }\end{array}$ & Dai 13765 & KM396793 & KM396844 & KP729317 & $\begin{array}{l}\text { Hailin City, Heilongjiang } \\
\text { Province, China }\end{array}$ \\
\hline 11 & $\begin{array}{l}\text { Auricularia } \\
\text { americana }\end{array}$ & Cui 9887 & KM396762 & KM396820 & KP729306 & $\begin{array}{l}\text { Yichun City, Heilongjiang } \\
\text { Province, China }\end{array}$ \\
\hline 12 & $\begin{array}{l}\text { Auricularia } \\
\text { americana }\end{array}$ & Dai 13476 & KM396764 & KM396821 & KT152126 & $\begin{array}{l}\text { AnTu County, Jilin Province, } \\
\text { China }\end{array}$ \\
\hline 13 & $\begin{array}{l}\text { Auricularia } \\
\text { auricula-judae }\end{array}$ & Dai 13210 & KM396769 & KM396824 & KP729312 & Lyon, France \\
\hline 14 & $\begin{array}{l}\text { Auricularia } \\
\text { auricula-judae }\end{array}$ & Dai 13549 & KM396770 & KM396825 & KP729313 & Lyon, France \\
\hline 15 & $\begin{array}{l}\text { Auricularia } \\
\text { cornea }\end{array}$ & Dai 13547 & KX022013 & KX022044 & KX022073 & $\begin{array}{c}\text { Danzhou City, Hainan Province, } \\
\text { China }\end{array}$ \\
\hline 16 & $\begin{array}{l}\text { Auricularia } \\
\text { cornea }\end{array}$ & Dai 15336 & KX022014 & KX022045 & KX022074 & $\begin{array}{l}\text { Nanning City, Guangxi Zhuang } \\
\text { Autonomous Region, China }\end{array}$ \\
\hline 17 & $\begin{array}{l}\text { Auricularia } \\
\text { delicata }\end{array}$ & Dai 16420 & KX022025 & KX022056 & KX022083 & $\begin{array}{c}\text { Lincang City, Yunnan Province, } \\
\text { China }\end{array}$ \\
\hline 18 & $\begin{array}{l}\text { Auricularia } \\
\text { delicata }\end{array}$ & Dai 11984 & KX022017 & KX022048 & KX022077 & $\begin{array}{c}\text { Baisha County, Hainan Province, } \\
\text { China }\end{array}$ \\
\hline 19 & $\begin{array}{l}\text { Auricularia } \\
\text { fuscosuccinea }\end{array}$ & FP-102573-SP & KX022027 & KX022058 & KX022088 & State of Louisiana, USA \\
\hline 20 & $\begin{array}{l}\text { Auricularia } \\
\text { fuscosuccinea }\end{array}$ & AG 1548 & KX022028 & KX022059 & KX022089 & Sao Paulo, Brazil \\
\hline 21 & $\begin{array}{l}\text { Auricularia } \\
\text { minutissima }\end{array}$ & Dai 14881 & KT152104 & KT152120 & KT152137 & $\begin{array}{l}\text { Baoding City, Hebei Province, } \\
\text { China }\end{array}$ \\
\hline 22 & $\begin{array}{l}\text { Auricularia } \\
\text { orientalis }\end{array}$ & Dai 14875 & KP729270 & KP729288 & KP729310 & $\begin{array}{l}\text { Baoding City, Hebei Province, } \\
\text { China }\end{array}$ \\
\hline 23 & $\begin{array}{l}\text { Auricularia } \\
\text { orientalis }\end{array}$ & Dai 1831 & KP729271 & KP729289 & KP729311 & Beijing, China \\
\hline 24 & Exidia truncata & MW 365 & AF291279 & AF291325 & _- & Germany \\
\hline
\end{tabular}

* - means sequenced by us, but did not submit to Genbank 
MCCJLAU0343.

\section{Phylogenetic analyses}

DNA extraction, PCR are according to Yan and Bau (2017). The ITS, LSU, RPB2 region was respectively amplified with ITS1 and ITS4 (White et al., 1990), LR0R and LR7 (Hopple and Vilgalys, 1999), 6F and 7.1R (Matheny et al., 2005). 24 sequences were selected for molecular phylogenetic analysis, based on results of BLAST, morphological similarities and referred to the studies of the (Wu et al., 2014) and (Malysheva \& Bulakh, 2014). 1988 characteristics, including gaps, were used in this study. Sequences were aligned by MUSCLE 3.8.31 (Edgar, 2004). The best model (GTR+I+G) was selected by AIC in Modeltest 3.7 (Posada et al., 1998). One million generations were set in Bayesian inference (BI) analyses with best model by MrBayes 3.2.6 (Ronquist \& Huelsenbeck, 2003) (Fig. 2).

\section{Culture medium preparation}

Medium A: yeast extract $2 \mathrm{~g}, \mathrm{KH}_{2} \mathrm{PO}_{4} 1 \mathrm{~g}, \mathrm{MgSO}_{4} 0.5 \mathrm{~g}$, agar $20 \mathrm{~g}$, distilled water $1000 \mathrm{~mL}$; Medium B: glucose $20 \mathrm{~g}, \mathrm{KH}_{2} \mathrm{PO}_{4} 1 \mathrm{~g}, \mathrm{MgSO}_{4} 0.5 \mathrm{~g}$, agar $20 \mathrm{~g}$, distilled water $1000 \mathrm{~mL}$; Medium C: glucose $20 \mathrm{~g}$, yeast extract $2 \mathrm{~g}, \mathrm{VB}_{1}$ $100 \mathrm{mg}$, agar $20 \mathrm{~g}$, distilled water $1000 \mathrm{~mL}$; Medium D: glucose $20 \mathrm{~g}$, yeast extract $2 \mathrm{~g}$, agar $20 \mathrm{~g}, \mathrm{MgSO}_{4} 0.5 \mathrm{~g}$, $\mathrm{KH}_{2} \mathrm{PO}_{4} 1 \mathrm{~g}$, distilled water $1000 \mathrm{~mL}$; Medium E: potato $200 \mathrm{~g}$, sugar $20 \mathrm{~g}$, soybean meal $2 \mathrm{~g}, \mathrm{KH}_{2} \mathrm{PO}_{4} 0.5 \mathrm{~g}$, agar $30 \mathrm{~g}$, distilled water $1000 \mathrm{~mL}$.

\section{Single factor test of carbon and nitrogen source}

The PDA medium used for the activated experiment contained (in distilled water): potato $200 \mathrm{~g} / \mathrm{L}$, glucose $20 \mathrm{~g} / \mathrm{L}$, agar $20 \mathrm{~g} / \mathrm{L}$, pH natural. When mycelia had grown all over Petri dishes, it was punched into $5 \mathrm{~mm}$ homogeneous pieces at the periphery of colonies by the puncher. These pieces of mycelia were used for the next experiment.

In the test of carbon source, $2 \%$ addition level of glucose, sugar, maltose, starch, lactose, CMC-Na, fructose was added individually to the basal medium A. A medium containing no carbon source was used as a control. These medium was autoclaved at $121^{\circ} \mathrm{C}$ for $30 \mathrm{~min}$. Mycelium was inoculated into the test medium by aseptic operation after autoclaving. Culture dishes were inoculated which then were put to incubator with $25^{\circ} \mathrm{C}$. All experiments were performed in sextuple. The diameter of colonies was measured every 24 hours and the mycelial growth was observed until the mycelium was covered with Petri dishes (Shim S M, 2005).

For the nitrogen source test, $2 \%$ addition level of yeast extract, peptone, beef extract, carbamide, $\mathrm{KNO}_{3}$, bran, soybean meal was added individually to the basal medium B. No added served as a control.

\section{Single factor test of inorganic salt and growth fac- tor}

On the basis of medium B, an inorganic salt concentration test was carried out. Three concentration gradients $(0.5 \%, 1 \%, 1.5 \%)$ were set for the three inorganic salts $\left(\mathrm{KH}_{2} \mathrm{PO}_{4}, \mathrm{MgSO}_{4}, \mathrm{KNO}_{3}\right)$.

Growth factors of vitamins (Vitamin C, Vitamin B1, Vitamin E), natural components (potato, bean sprout, malt extract, hay, mushroom, corn) were tested. Apart from out natural components, $0.01 \mathrm{~g} / \mathrm{L}$ addition level was added individually to the basal medium C. 8 natural components which was severally weighed $20 \mathrm{~g} / \mathrm{L}$ and boiled the juice with distilled water, filtered was added individually to the basal medium. No added as control (Tie LU, 2007).

\section{Orthogonal test}

The orthogonal $\mathrm{L}_{9}\left(3^{4}\right)$ was used to obtain the optiomal medium in mycelium cultures. Medium D used as the basal medium. For the above four factors(carbon source, nitrogen source, inorganic salt, growth factor) was respectively selected best three levels to carried out the four factors of exercise at three levels orthogonal design (Lu T, 2013).

\section{Single factor test of temperature and pH}

Based on the optimal medium of mycelicum cultures were obtained by orthogonal test. To investigate the temperature favorable for the mycelial growth of $A$. villosula, the fungus was incubated for 10 days at 5 different temperature. Medium E used as the basal medium. These medium were put to incubator with 15, 20, 25, 30 and $35^{\circ} \mathrm{C}$, individually. $\mathrm{pH}$ natural.

To screen $\mathrm{pH}$ favorable to the mycelial growth of $A$. villosula, the basal medium $\mathrm{E}$ adjust to the range of $\mathrm{pH} 5,6,7,8,8.5$ with $1 \mathrm{M} \mathrm{NaOH}$ or $\mathrm{HCl}$ was incubated for 10 days at $25^{\circ} \mathrm{C}$ (Rizal L M, 2015).

\section{Domesticated cultivation experiment}

In the domestication experiments of $A$. villosula, the stages of pre-culture spawn, of manufacturing cultural bags, of spawn running, of inducement to primordium, of fruiting period management, of collected periods were studied.

\section{RESULT AND DISCUSSIONS}

\section{Taxonomy and Phylogenetic analysis}

Auricularia villosula Malysheva, in Malysheva \& Bulakh, Nov. sist. Niz. Rast. 48: 174 (2014)

Basidiomata gelatinous when fresh, solitary, or caespitose, rarely caespitose, discoid to auriculate, with even and white margin, projecting up 15-60 mm broad, 0.5-1.0 mm thick. Hymenophore surface usually smooth or rarely folds, pale brown. Upper surface with obviously white abhymenial hairs $49-122 \times 4.9-7.3 \mu \mathrm{m}$. Shrinkage, solidly, dark brown to black. Internal features. Medulla present, abhymenial hairs, 49-122×4.9-7.3 $\mu \mathrm{m}$, irregular, hyaline or with slightly fawn, thick-walled with a narrow separated lumen or subsolid, apical tips acute or obtuse, usually tufted. Clamp connections present. Basidia 58-85 × 4.9-6.1 $\mu \mathrm{m}$, clavate, transversely 3-septate, sterigmata rarely observed. Spores (9.0)11.4-14.8 (16.8) $\times$ $4.1-7.8 \mu \mathrm{m}, \mathrm{Q}=1.7-2.4(2.8)$, allantoid, hyaline, thinwalled, smooth, usually guttulate containing one guttules. 
Conidia 14.4-19.8(21.7) $\times(5.4) 7.1-10.5 \mu \mathrm{m}$, massive, hyaline, septate and slightly constricted at middle or non-septate, non- constricted (Fig. 1).

Habit and habitat: - solitary or caespitose on Artemisia ordosica in desert.

Material examined:-CHINA. Inner Mongolia Autonomous Region: Erdos city. 12-sep-2016, Tolgor Bau, HMJAU 37794.

Note: Our specimen with medulla and grown on Artemisia ordosica Krasch. (subshrub), a little differ to the type of $A$. villosula. But polygenic analysis shows that our specimen and type are group together with high statistical support value $(\mathrm{BPP}=1)$ (Fig. 2). It is finally identified as $A$. villosula, based on morphological char- acteristics and polygenic analysis.

\section{Effect of carton sources and nitrogen on mycelia growth}

Mycelium can grow on 8 carbon and nitrogen sources, but sugar and soybean meal were screened as carbon and nitrogen sources suitable for the mycelial growth of A. villosula (Table 2, Table3, Fig. 3). After 10 days of incubation, the mycelial growth rate of $A$. villosula recorded $4.30 \pm 0.46 \mathrm{~mm}$ in sugar and $4.79 \pm 0.25 \mathrm{~mm}$ in soybean meal, respectively. Among the carbon sources tested, the highest mycelial growth rate was obtained with sugar, followed by fructose and maltose. The rest of carbon sources are in order, lactose, glucose, CK. The

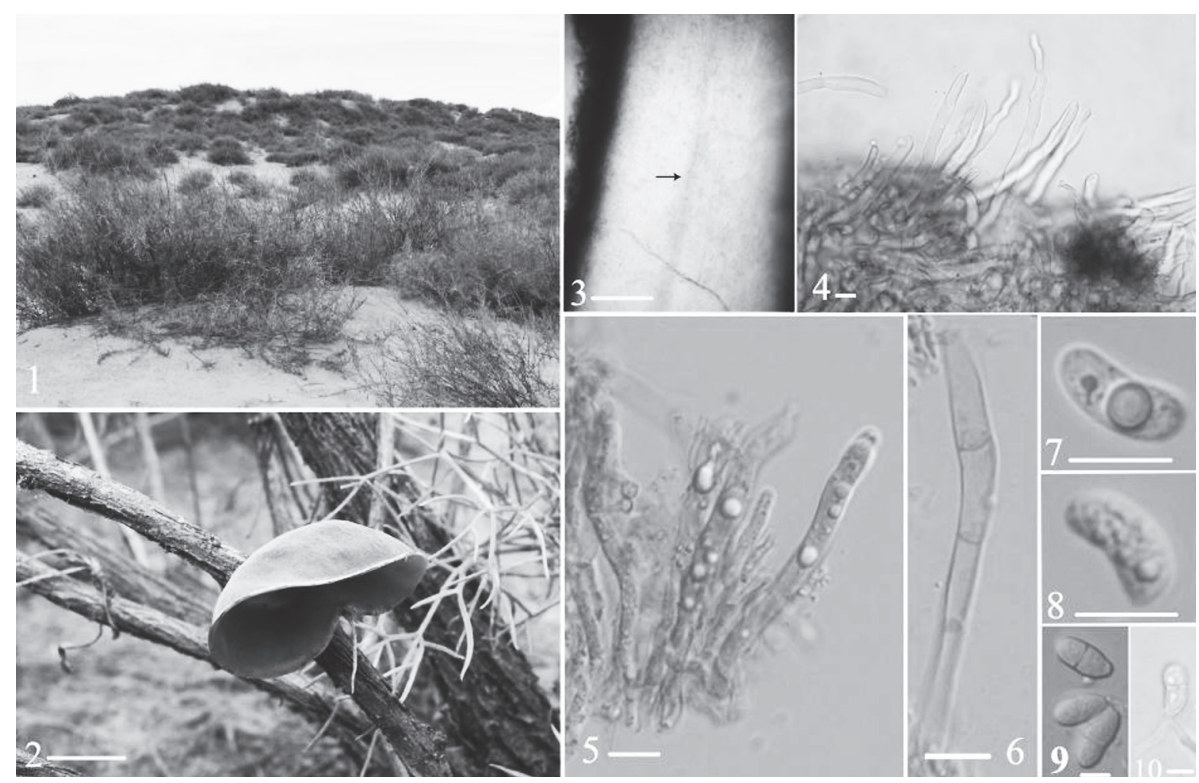

Fig. 1. Auricularia villosula (HMJAU37794) 1-2. Habitat and Basidioma; 3. Arrow for medulla; 4. Abhymenial hairs; 5-6. Basidia and Basidioles; 7-8. Basidiospores; 9-10. Conidia. Bars $2=10 \mathrm{~mm} ; 3=200 \mu \mathrm{m} ; 4-9=10 \mu \mathrm{m}$. Photo by Tolgor Bau.

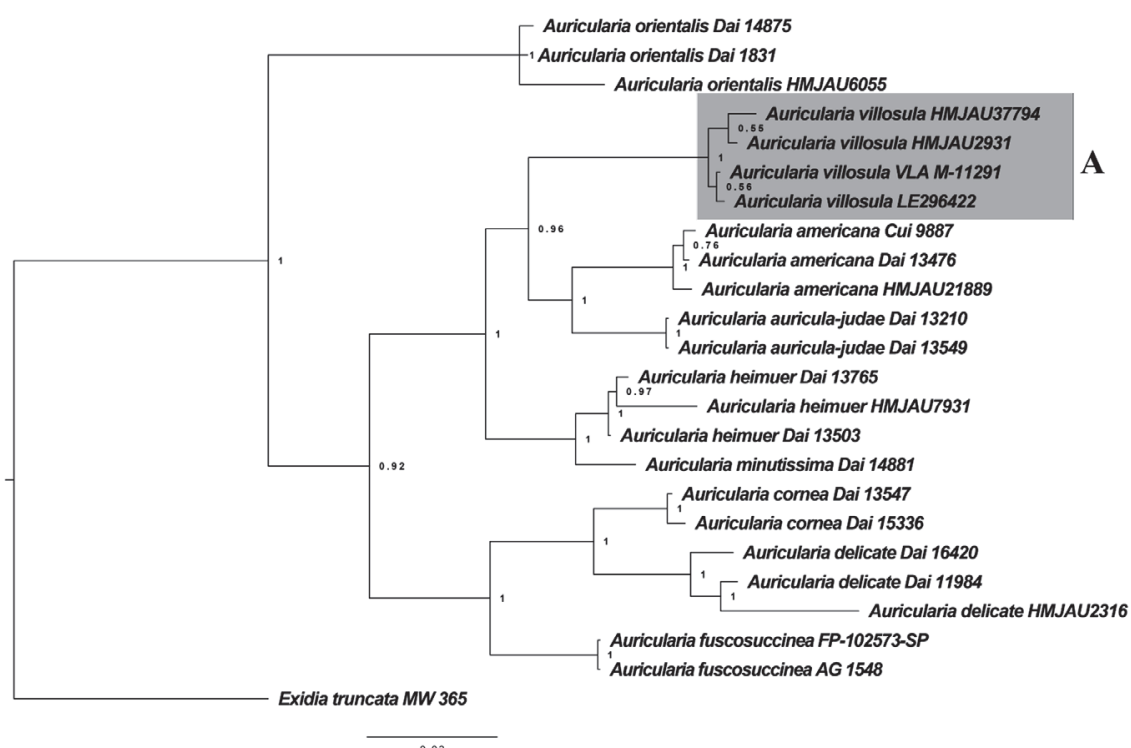

Fig. 2. Bayesian phylogenetic tree inferred from ITS + nLSU + RPB2 sequences. 
Table 2. Effect of carbon sources on mycelial growth of Auricularia villosula

\begin{tabular}{ccccc}
\hline $\begin{array}{c}\text { Carbon } \\
\text { source }\end{array}$ & $\begin{array}{c}\text { Mycelial } \\
\text { growth rate } \\
(\mathrm{mm} / \mathrm{d})^{*}\end{array}$ & $\begin{array}{c}\text { Significance } \\
\text { levels }\end{array}$ & $\begin{array}{c}\text { Mycelial } \\
\text { growth vigor } \\
(\mathrm{mm} / \mathrm{d}) * *\end{array}$ \\
\hline Sucrose & $4.30 \pm 0.46$ & $\mathrm{ab}$ & $\mathrm{A}$ & +++ \\
Fructose & $4.25 \pm 0.35$ & $\mathrm{ab}$ & $\mathrm{A}$ & +++ \\
Maltose & $4.20 \pm 0.35$ & $\mathrm{ab}$ & $\mathrm{A}$ & +++ \\
Lactose & $4.19 \pm 0.24$ & $\mathrm{ab}$ & $\mathrm{A}$ & +++ \\
Glucose & $4.06 \pm 0.33$ & $\mathrm{a}$ & $\mathrm{A}$ & +++ \\
CK & $3.95 \pm 0.39$ & $\mathrm{c}$ & $\mathrm{B}$ & +++ \\
Soluble Starch & $3.72 \pm 0.60 \mathrm{f}$ & $\mathrm{a}$ & $\mathrm{A}$ & +++ \\
CMC-Na & $1.12 \pm 0.32$ & $\mathrm{~b}$ & $\mathrm{~A}$ & ++ \\
\hline
\end{tabular}

* Date represent the average values of six replicates.

** " +++ " vigorous mycelial growth, "++" intermediate mycelial growth, "+" weak mycelial growth.

Table 3. Effects of nitrogen sources on mycelial growth of Auricularia villosula

\begin{tabular}{ccccc}
\hline $\begin{array}{c}\text { Nitrogen } \\
\text { source }\end{array}$ & $\begin{array}{c}\text { Mycelial } \\
\text { growth rate } \\
(\mathrm{mm} / \mathrm{d}) *\end{array}$ & $\begin{array}{c}\text { Significance } \\
\text { levels }\end{array}$ & $\begin{array}{c}\text { Mycelial } \\
\text { growth vigor } \\
(\mathrm{mm} / \mathrm{d})^{* *}\end{array}$ \\
\hline Soybean meal & $4.79 \pm 0.25$ & $\mathrm{e}$ & $\mathrm{E}$ & ++ \\
Bran & $4.61 \pm 0.31$ & $\mathrm{~d}$ & $\mathrm{D}$ & ++ \\
Yeast extract & $4.36 \pm 0.32$ & $\mathrm{~b}$ & $\mathrm{~B}$ & +++ \\
CK & $3.17 \pm 0.15$ & $\mathrm{a}$ & $\mathrm{A}$ & ++ \\
Potassium nitrate & $2.86 \pm 0.33$ & $\mathrm{c}$ & $\mathrm{C}$ & ++ \\
Beef extract & $2.30 \pm 0.41$ & $\mathrm{f}$ & $\mathrm{F}$ & +++ \\
Peptone & $1.43 \pm 0.11$ & $\mathrm{ab}$ & $\mathrm{AB}$ & +++ \\
Carbamide & $0.02 \pm 0.05$ & $\mathrm{c}$ & $\mathrm{C}$ & ++ \\
\hline
\end{tabular}

*,** As in Table 1
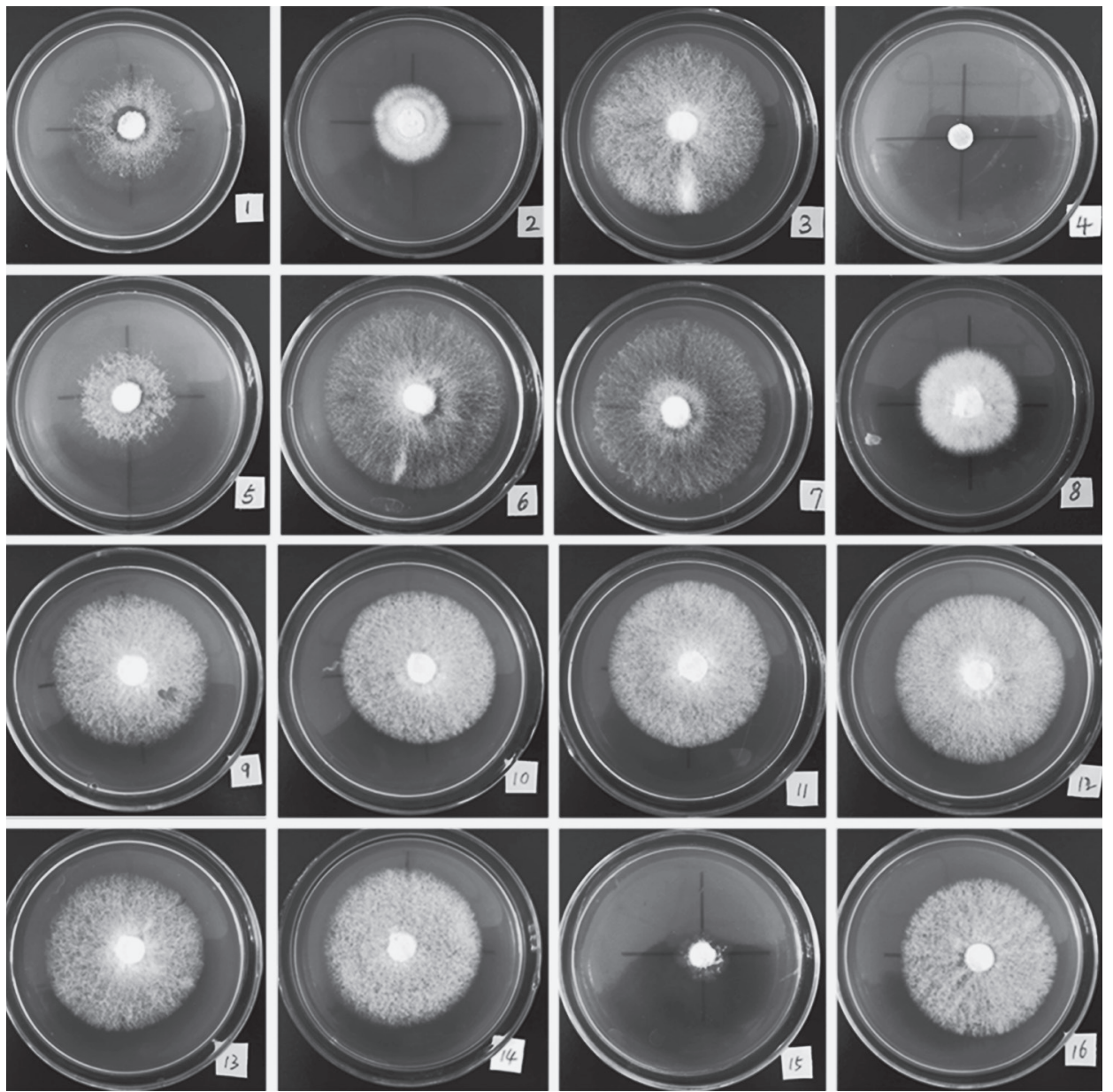

Fig. 3. Colony diameter of $A$. villosula at different Nitrogen source and 1. CK. 2. Peptone. 3. Yeast extract. 4. Carbamide. 5. Potassium nitrate. 6. Bran 7. Soybean meal. 8. Beef extract. 9. Glucose 10. Soluble Starch. 11. Maltose. 12. Sucrose. 13. Fructose.14. Lactose. 15. CMC-Na. 16. CK.

worst are soluble Starch, CMC-Na, these carbon sources were less than control. Apart from outside CMC-Na, the mycelial growth vigor of other carbon sources was more effiectively. Among the nitrogen sources tested, the highest mycelial growth rate was obtained with soybean meal, followed by bran and yeast extract. They are better than control. The Carbamide was the worst, because in the process of autoclaving produced ammonia, mycelium death. From the point of mycelial growth vigor, Yeast extract is more suitable than soybean meal, but also econ- 
omy. Therefore, the three carbon (sugar, fructose, maltose) and nitrogen sources (soybean meal, bran, yeast extract) were selected as the optimal condition in the following experiments through comprehensive consideration.

Table 4. Effects of inorganic salt concentrationon mycelial growth of Auricularia villosula

\begin{tabular}{ccccc}
\hline $\begin{array}{c}\text { Inorganic salt } \\
\text { concentration }\end{array}$ & $\begin{array}{c}\text { Mycelial } \\
\text { growth rate } \\
(\mathrm{mm} / \mathrm{d})^{*}\end{array}$ & \multicolumn{2}{c}{$\begin{array}{c}\text { Significance } \\
\text { levels }\end{array}$} & $\begin{array}{c}\text { Mycelial } \\
\text { growth vigor } \\
(\mathrm{mm} / \mathrm{d})\end{array}$ \\
\hline $0.5 \% \mathrm{~K}^{+}$ & $4.91 \pm 0.37$ & $\mathrm{a}$ & $\mathrm{A}$ & +++ \\
$0.5 \% \mathrm{PO}_{4}{ }^{3-}$ & $4.83 \pm 0.36$ & $\mathrm{ab}$ & $\mathrm{AB}$ & +++ \\
$1 \% \mathrm{Mg}^{2+}$ & $4.69 \pm 0.25$ & $\mathrm{bc}$ & $\mathrm{ABC}$ & +++ \\
$\mathrm{CK}$ & $4.55 \pm 0.19$ & $\mathrm{abcd}$ & $\mathrm{ABC}$ & +++ \\
$1 \% \mathrm{~K}^{+}$ & $4.51 \pm 0.40$ & $\mathrm{abcd}$ & $\mathrm{ABC}$ & +++ \\
$0.5 \% \mathrm{Mg}^{2+}$ & $4.47 \pm 0.40$ & $\mathrm{a}$ & $\mathrm{ABC}$ & +++ \\
$1 \% \mathrm{PO}_{4}{ }^{3-}$ & $4.36 \pm 0.28$ & $\mathrm{~cd}$ & $\mathrm{ABC}$ & +++ \\
$1.5 \% \mathrm{Mg}^{2+}$ & $4.34 \pm 0.16$ & $\mathrm{~cd}$ & $\mathrm{BC}$ & +++ \\
$1.5 \% \mathrm{PO}_{4}{ }^{3-}$ & $4.31 \pm 0.40$ & $\mathrm{~cd}$ & $\mathrm{BC}$ & +++ \\
$1.5 \% \mathrm{~K}^{+}$ & $4.15 \pm 0.30$ & $\mathrm{~d}$ & $\mathrm{C}$ & +++ \\
\hline
\end{tabular}

*,** As in Table 1
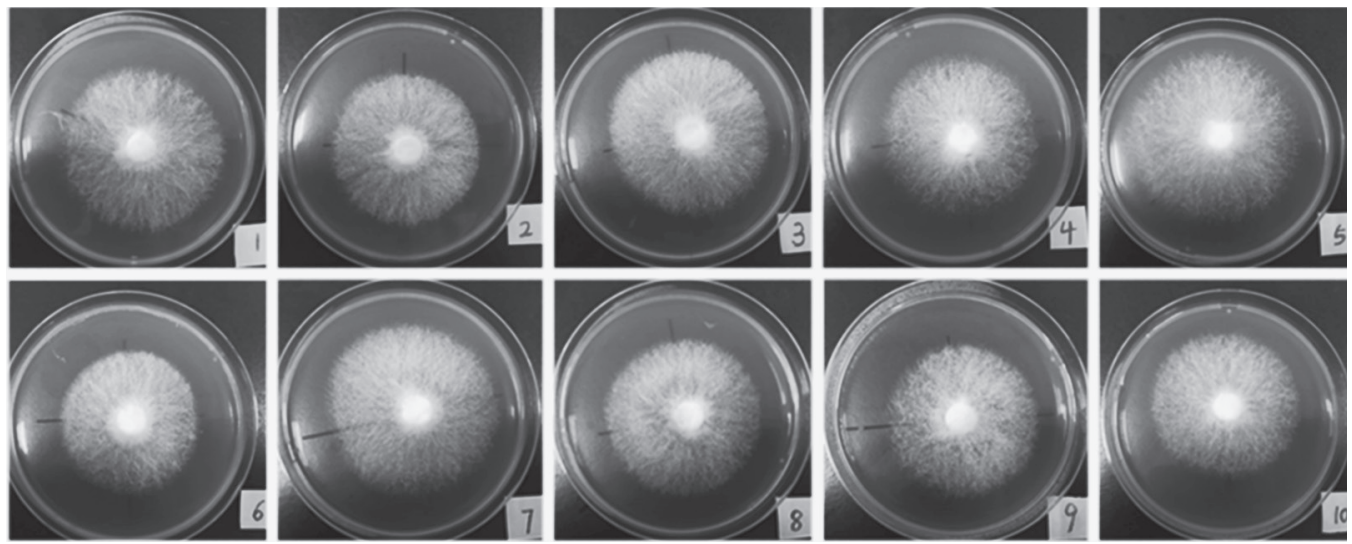

Fig. 4. Colony diameter of $A$. villosula at different Inorganic salt1. $0.5 \% \mathrm{PO}_{4}^{3-}$. 2. $1 \% \mathrm{PO}_{4}^{3-}$. 3. $1.5 \% \mathrm{PO}_{4}{ }^{3-}$. 4. $0.5 \% \mathrm{Mg}^{2+}$. 5. $1 \% \mathrm{Mg}^{2+}$. 6. $1.5 \% \mathrm{Mg}^{2+}$. $.0 .5 \% \mathrm{~K}^{+}$. 8. $1 \% \mathrm{~K}^{+}$. 9. $1.5 \% \mathrm{~K}^{+}$. 10. CK.
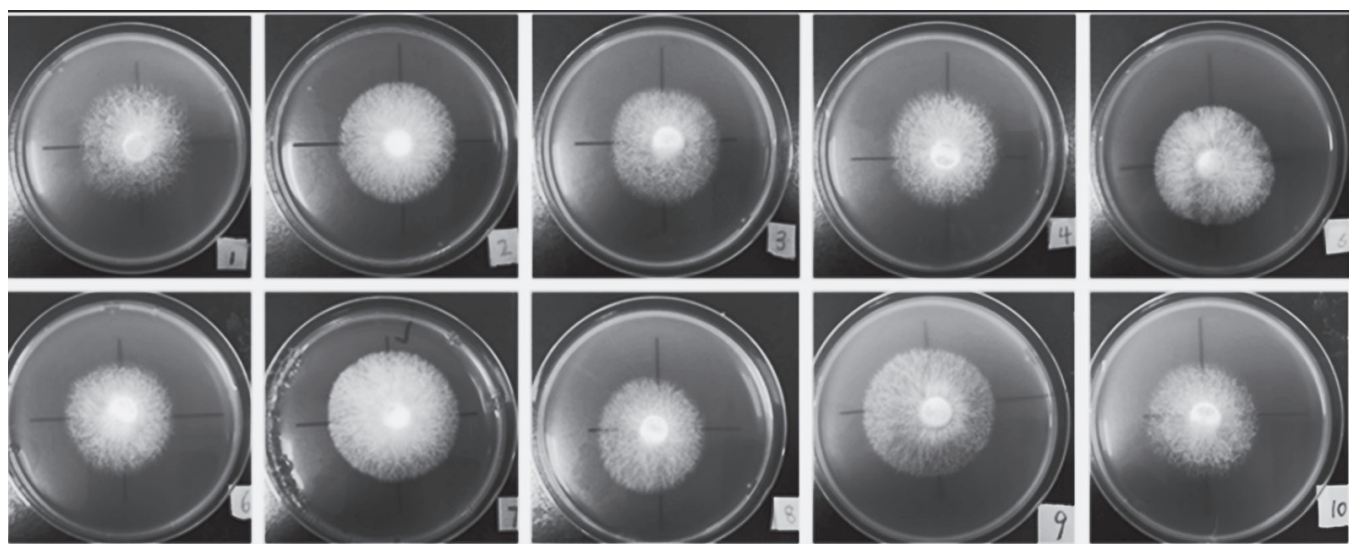

Fig. 5. Colony diameter of A.villosula at different Growth factors 1. Potato. 2. Bean sprout. 3. VC. 4. VB. 5. Hay. 6. Malt extract 7. Mushroom. 8. VE. 9. Corn. 10.CK. 
Table 6. The results of direct-viewing analysis of mycelial growth

\begin{tabular}{|c|c|c|c|c|c|c|}
\hline $\begin{array}{c}\text { Text } \\
\text { Number }\end{array}$ & $\begin{array}{l}\text { Carbon } \\
\text { source }\end{array}$ & $\begin{array}{l}\text { Nitrogen } \\
\text { source }\end{array}$ & $\begin{array}{l}\text { Inorganic salt } \\
\text { concentration }\end{array}$ & $\begin{array}{l}\text { Growth } \\
\text { factor }\end{array}$ & $\begin{array}{c}\text { Mycelial growth } \\
\text { rate } \\
(\mathrm{mm} / \mathrm{d})^{*}\end{array}$ & $\begin{array}{c}\text { Mycelial growth } \\
\text { vigor } \\
(\mathrm{mm} / \mathrm{d})^{* *}\end{array}$ \\
\hline 1 & 1Maltose & 1soybean meal & $1\left(0.5 \% \mathrm{~K}^{+}\right)$ & 1Mushroom & 2.00 & +++ \\
\hline 2 & 1Maltose & 2Yeast extract & $2\left(0.5 \% \mathrm{PO}_{4}^{3-}\right)$ & 2Bean sprout & 2.10 & +++ \\
\hline 3 & 1Maltose & 3Bran & $3\left(1 \% \mathrm{Mg}^{2+}\right)$ & 3Potato & 2.31 & +++ \\
\hline 4 & 2Sucrose & 1soybean meal & $2\left(0.5 \% \mathrm{PO}_{4}^{3-}\right)$ & 3Potato & 2.50 & +++ \\
\hline 5 & 2Sucrose & 2Yeast extract & $3\left(1 \% \mathrm{Mg}^{2+}\right)$ & 1Mushroom & 2.06 & +++ \\
\hline 6 & 2Sucrose & 3Bran & $1\left(0.5 \% \mathrm{~K}^{+}\right)$ & 2Bean sprout & 2.06 & +++ \\
\hline 7 & 3Fructose & 1soybean meal & $3\left(1 \% \mathrm{Mg}^{2+}\right)$ & 2Bean sprout & 1.92 & +++ \\
\hline 8 & 3Fructose & 2Yeast extract & $1\left(0.5 \% \mathrm{~K}^{+}\right)$ & 3Potato & 2.13 & +++ \\
\hline 9 & 3Fructose & 3Bran & $2\left(0.5 \% \mathrm{PO}_{4}^{3-}\right)$ & 1Mushroom & 1.90 & +++ \\
\hline $\mathrm{T}_{1}$ & 38.50 & 38.50 & 37.13 & 35.75 & \multirow{3}{*}{\multicolumn{2}{|c|}{$\mathrm{T}=18.98$}} \\
\hline $\mathrm{T}_{2}$ & 39.75 & 37.75 & 39.00 & 36.50 & & \\
\hline $\mathrm{T}_{3}$ & 35.63 & 37.63 & 37.75 & 41.63 & & \\
\hline $\mathrm{X}_{1}$ & 2.14 & 2.14 & 2.06 & 1.99 & & \\
\hline $\mathrm{X}_{2}$ & 2.21 & 2.10 & 2.17 & 2.03 & & \\
\hline $\mathrm{X}_{3}$ & 1.98 & 2.09 & 2.10 & 2.31 & & \\
\hline $\mathrm{R}$ & 0.23 & 0.05 & 0.10 & 0.33 & & \\
\hline
\end{tabular}

Table 7. The results of F-test of mycelial growth

\begin{tabular}{cccccc}
\hline Source & $\begin{array}{c}\text { TypeIISum of } \\
\text { squares }\end{array}$ & $d f$ & Mean square & $F$ & Significance \\
\hline Carbon source & 0.50 & 2 & 0.25 & 3.74 & 0.0315 \\
Nitrogen source & 0.02 & 2 & 0.01 & 0.19 & 0.8300 \\
Inorganicsalt concentration & 0.10 & 2 & 0.05 & 0.76 & 0.4729 \\
Growth factor & 1.14 & 2 & 0.57 & 8.54 & 0.0007 \\
Error & 2.99 & 45 & 0.07 & & \\
Total & 3.95 & & & & \\
\hline
\end{tabular}

was more better than control. Others not only do not benefit, but also inhibit growth. For the growth factors test, mushroom, potato and bean sprout are good candidates for the growth factors compared with other growth factors. Malt extract and hay were no effective from control. Therefore, the three inorganic salts $\left(0.5 \% \mathrm{~K}^{+}\right.$, $0.5 \% \mathrm{PO}_{4}^{3-}, 1 \% \mathrm{Mg}^{2+}$ ) and growth factors (mushroom, potato, bean sprout) were selected as the optimal condition in the following experiments through comprehensive consideration (Zhu Y, 2011).

\section{Effect of orthogonal text on mycelial growth}

From the carbon source, nitrogen source, growth factor and inorganic salt concentration in the single factor test, the best three types were selected as the three levels, and the orthogonal analysis of four factors and three levels was established (Table 6, Table 7, Fig. 6). Visual analysis showed that the growth factor. The range is 0.33 , followed by carbon source, inorganic salt concentration and nitrogen source. Optimum formulation:

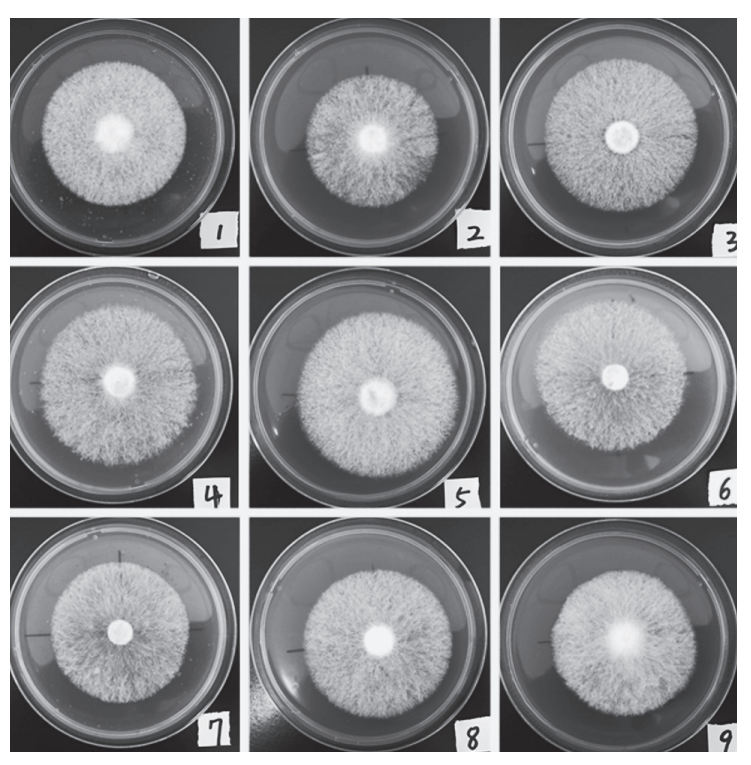

Fig. 6. Colony diameter of $A$. villosula at Orthogonal text 1. Text 1. 2. Text 2. 3. Text 3. 4. Text 4. 5. Text 5.6. Text 6. 7. Text 7. 8. Text 8. 9. Text 9. 
carbon source X2, nitrogen source X1, inorganic salt concentration X2, growth factor X3, fourth group sucrose, soybean meal, $0.5 \% \mathrm{PO}_{4}^{3-}$, potatoes were determined.

The orthogonal test results were analyzed by variance. The $\mathrm{F}$ value of growth factor was the highest, followed by carbon source, inorganic salt concentration and nitrogen source. Therefore, the significance difference of the four factors is the growth factor, the carbon source, the inorganic salt concentration and the nitrogen source, successively. This is consistent with the results of intuitive analysis.

\section{Effect of temperature and $\mathrm{pH}$ on mycelial growth}

The temperature experiment was carried out under the optimum formulation selected for orthogonal test (Table 8, Table 9). The mycelium of $A$. villosula could grow at the temperature range of $15^{\circ} \mathrm{C} \sim 35^{\circ} \mathrm{C}$, and the mycelial growth rate showed that very significant difference at different temperatures. When the temperature is $30^{\circ} \mathrm{C}$, mycelium growth fastest, mycelium was white and dense, strong growth potential, so consider $30^{\circ} \mathrm{C}$ for the shortest fungus mycelium optimum growth temperature. And when the temperature was $35^{\circ} \mathrm{C}$, mycelial growth rate was significantly inhibited by slowing down. The mycelial growth rate of $A$. villosula showed that no significant difference. When $\mathrm{pH} 8$, the mycelium fastest growing, better growth, mycelium thick. And pH 8.5, the mycelium slow down significantly; $\mathrm{pH} 5$, the mycelium growth is weakest. So, it is suitable for alkaline culture.

Table 8. Effecst of temperature on mycelial growth of Auricularia villosula

\begin{tabular}{ccccc}
\hline Temperature & $\begin{array}{c}\text { Mycelial } \\
\text { growth rate } \\
(\mathrm{mm} / \mathrm{d})^{*}\end{array}$ & $\begin{array}{c}\text { Significance } \\
\text { levels }\end{array}$ & $\begin{array}{c}\text { Mycelial } \\
\text { growth vigor } \\
(\mathrm{mm} / \mathrm{d}) * *\end{array}$ \\
\hline $15^{\circ} \mathrm{C}$ & $0.83 \pm 0.16$ & $\mathrm{a}$ & $\mathrm{A}$ & +++ \\
$20^{\circ} \mathrm{C}$ & $1.87 \pm 0.25$ & $\mathrm{~b}$ & $\mathrm{~B}$ & +++ \\
$25^{\circ} \mathrm{C}$ & $2.40 \pm 0.78$ & $\mathrm{c}$ & $\mathrm{BC}$ & +++ \\
$30^{\circ} \mathrm{C}$ & $3.88 \pm 0.12$ & $\mathrm{~d}$ & $\mathrm{C}$ & +++ \\
$35^{\circ} \mathrm{C}$ & $2.98 \pm 0.42$ & $\mathrm{e}$ & $\mathrm{D}$ & +++ \\
\hline
\end{tabular}

Table 9. Effects of pH on mycelial growth of Auricularia villosula

\begin{tabular}{ccccc}
\hline pH & $\begin{array}{c}\text { Mycelial } \\
\text { growth rate } \\
(\mathrm{mm} / \mathrm{d})^{*}\end{array}$ & $\begin{array}{c}\text { Significance } \\
\text { levels }\end{array}$ & $\begin{array}{c}\text { Mycelial } \\
\text { growth vigor } \\
(\mathrm{mm} / \mathrm{d}) * *\end{array}$ \\
\hline 5 & $3.18 \pm 0.12$ & $\mathrm{a}$ & $\mathrm{A}$ & +++ \\
6 & $3.28 \pm 0.44$ & $\mathrm{a}$ & $\mathrm{A}$ & +++ \\
7 & $3.22 \pm 0.59$ & $\mathrm{a}$ & $\mathrm{A}$ & +++ \\
8 & $3.33 \pm 0.44$ & $\mathrm{a}$ & $\mathrm{A}$ & +++ \\
8.5 & $3.23 \pm 0.53$ & $\mathrm{a}$ & $\mathrm{A}$ & +++ \\
\hline
\end{tabular}

\section{Cultivation}

Pre-culture spawn

Solid medium: Boiled corn with distilled water, then filled bottle (Jwanny E W, 1995) (Fig. 7).

Liquid medium: $1000 \mathrm{~mL}$ fermentation medium, yeasy extract $20 \mathrm{~g}$, glucose $20 \mathrm{~g}$, peptone $10 \mathrm{~g}, \mathrm{KH}_{2} \mathrm{PO}_{4}$ $1 \mathrm{~g}, \mathrm{MgSO}_{4} 0.5 \mathrm{~g}$, and with the conditions of culture: $150 \mathrm{r} / \mathrm{min}, 7$ days at $25^{\circ} \mathrm{C}(\mathrm{Ma} \mathrm{J}, 2011)$ (Fig. 8).

They were autoclaved at $121^{\circ} \mathrm{Cfor} 2 \mathrm{~h}$. To inoculated 10 days.

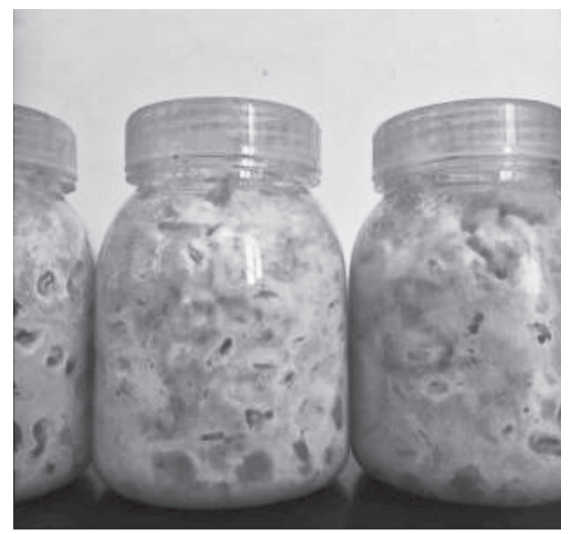

Fig. 7. Mycelial growth of $A$. villosula at Solid medium.

\section{Manufacturing cultural bags}

The following recipe of the cultivation medium was used: sawdust $78 \%$, bran $20 \%$, lime $1 \%$, plaster $1 \%$, with water stir evenly and put it in bag $(17 * 30 \mathrm{~cm})$, and autoclaved at $121^{\circ} \mathrm{C}$ for $2 \mathrm{~h}$. Cultivation bags required water content of about $65 \%$. $10 \mathrm{~mL}$ liquid spawn per cultural bag was used for inculation (Bonatti M, 2004).

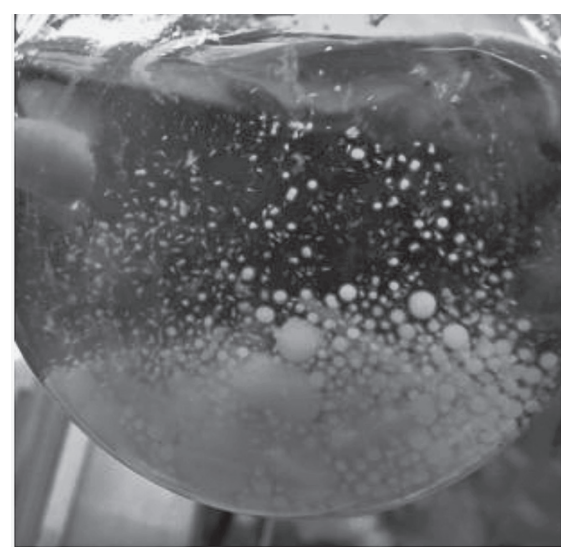

Fig. 8. Mycelial growth of $A$. villosula at Liquid medium.

\section{Spawn running}

Clean environment was essential in order to prevent contamination. The optimal condition for this stage was to keep a steady temperature of $20 \sim 25^{\circ} \mathrm{C}$ and darkness, ventilation for about 15 days (Fig. 9). 


\section{Inducement to primordium}

After mycelium of culture bag was full up to $10 \sim 15 \mathrm{~d}$ physiological state of maturity can be moved fruiting induced ear chamber. This time, make the mouth for the bag was required (Fig. 10).

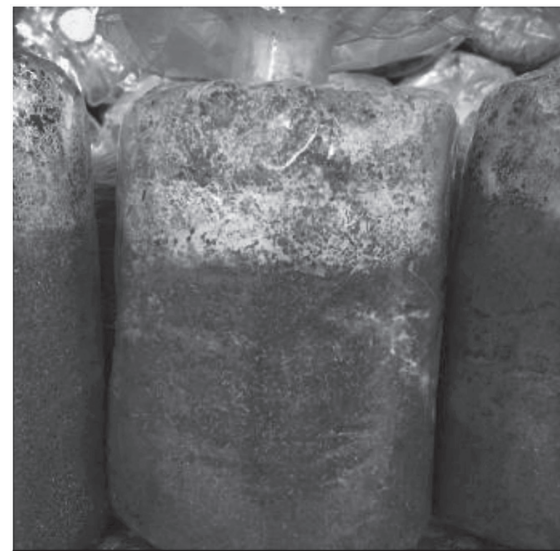

Fig. 9. Spawn running stage of $A$. villosula.

\section{Fruiting period management}

The optimal temperature range was $22 \sim 30^{\circ} \mathrm{C}$, and relative humidity range was $80 \% \sim 90 \%$, ventilation was needed (B Gizaw 2010) (Fig. 11).

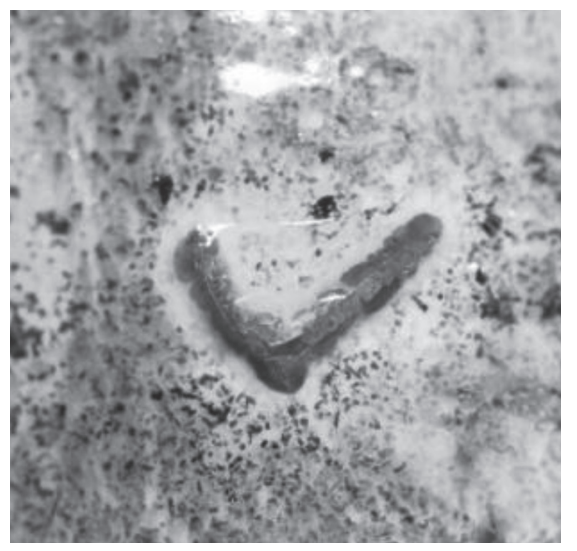

Fig. 10. Inducement to primordium.

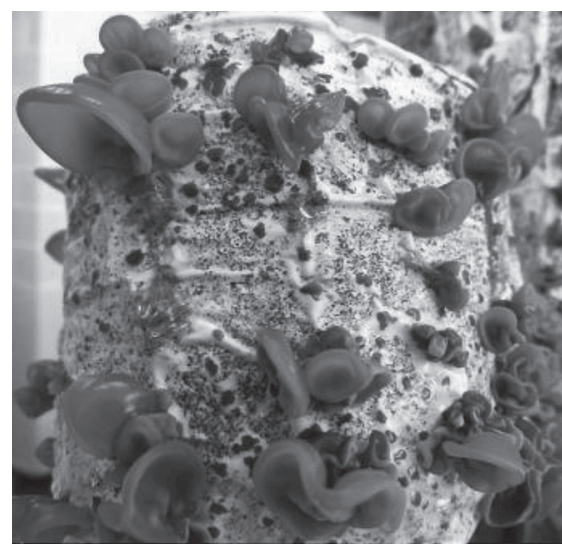

Fig. 11. Fruiting priod.

\section{Harvest}

To be ear piece of $A$. villosula stretch, the edge began to shrink when the harvest can be. To timely one-time harvest, the whole ears even pull out. The cultivated fruiting bodies showed the appearance identical to the wild ones under optimal condition (Fig. 12).

The optimal growth conditions of the mycelium were determined by the single factor experiment of the carbon source, the nitrogen source, the inorganic salt concentration, the growth factor single factor experiment and the orthogonal test. The optimum growth conditions were as follows: temperature $30^{\circ} \mathrm{C}, \mathrm{pH} 8$, Carbon source is sucrose, nitrogen source is soybean meal, inorganic salt concentration of $0.5 \% \mathrm{PO}_{4}^{3-}$, growth factor for potato juice. Mycelium best culture temperature of $30^{\circ} \mathrm{C}$, need ventilation, dark. Fruiting body growth temperature 21 $27^{\circ} \mathrm{C}$, air humidity $80 \% \sim 90 \%$. Ears should be collected before the ejection of spores, harvest ear pieces should be placed in the gauze dry.

So far, $A$. heimuer, $A$. conera and $A$. delicata are have been cultivated widely. A. heimuer and $A$. conera is the most extensive cultivation area, the highest yield. Due to the demand in the process of the development of the mycelium is different, so the physiological characteristics of different strains and culture characteristics are different. In this paper, for the mycelium growth of $A$. villosula, the optimal carbon source is sucrose, however, $A$. heimuer and $A$. delicata is sources too, and the $A$. conera is glucose; the optimal nitrogen source is soybean meal, and $A$. heimuer is yeast extract, $A$. delicata and $A$. conera is beef extract; the optimal tempreture is $30^{\circ} \mathrm{C}$, and $A$. heimuer is $30^{\circ} \mathrm{C}, A$. delicata and $A$. conera is $25^{\circ} \mathrm{C}$ (Wang jing, 2013; Wu Rengao, 2010; Wang $\mathrm{J}$, 2014).

In this study, the biological characteristics and domestication of $A$. villosula were studied, and the basic research data of biological characteristics was provided for the better utilization of this resource. A follow-up study of $A$. villosula can be carried out in the areas of mycelial liquid deep fermentation, yield optimization, variety breeding and pharmacological active ingredients.

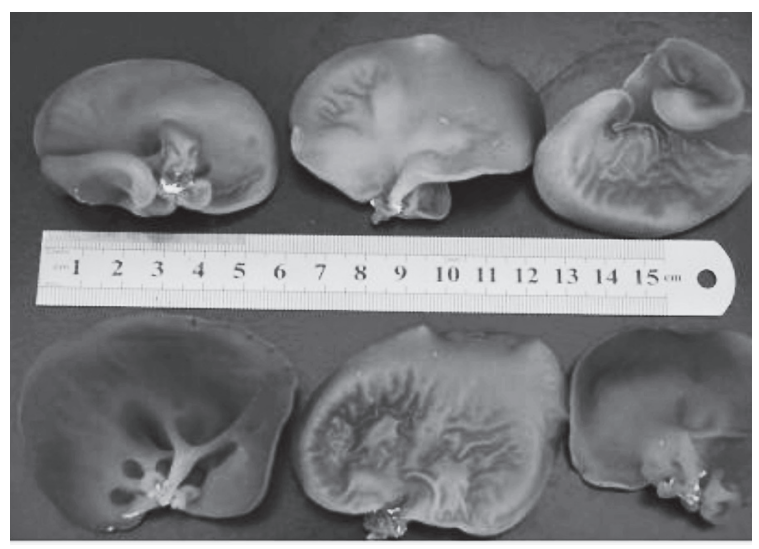

Fig. 12. Fruiting body of cultivation. 


\section{AUTHOR CONTRIBUTIONS}

X.Y. ZHANG designed the study, performed the microscopic observation, DNA analysis and wrote the paper. T. BAU performed the genetic experiment. T. BAU and S. OHGA designed the study, supervised the work. All authors assisted in editing the manuscript and approved the final version.

\section{ACKNOWLEGEMENT}

Project supported by the Program for Changjiang Scholars and Innovative Research Team in University of Ministry of Education of China (Grant No. IRT15R25).

\section{REFERENCES}

Bandara, A. R., Chen, J., Karunarathna, S., Hyde, K. D., \& Kakumyan, P. 2015 Auricularia thailandica sp. nov. (Auriculariaceae, Auriculariales) a widely distributed species from Southeastern Asia. Phytotaxa, 208(2): 147-156

Bonatti M, Karnopp P, Soares H M, et al. 2004 Evaluation of Pleurotus ostreatus and Pleurotus sajor-caju nutritional characteristics when cultivated in different lignocellulosic wastes. Food Chemistry, 88(3): 425-428

Bulliard, J. B. F. 1780 Herbier de la France. 7: 289-336

Dai, Y. C., Bau, T., 2007 Illustration of edible and medicinal fungi in northeastern China. Science Press, Beijing, 1-231

Edgar. 2004 Die Geburt der Gegenstandstheorie aus einem Missverständnis?: Phenomenology \& Analysis Essays in Central European Philosophy[J]. Chemical Geology, 238(12): $107-120$

FAN Xiu-Zhi, LI Li, CHEN Lian-Fu, XIAO Yang, BIAN Yin-Bing, 2014 Phylogeny of Auricularia spp. inferred from nuclear ribosomal DNA and gpd gene sequences, Proceedings of the Tenth National Symposium on edible fungi, 17-24

Ge, Y., Yang, S., \& Bau, T. 2017 Crepidotus lutescens sp. nov. (Inocybaceae, Agaricales), an ochraceous salmon colored species from northeast of China. Phytotaxa, 297(2): 189-196

Gizaw B. 2010 Cultivation and yield performance of Pholiota nameko on different agro industrial wastes. Addis Ababa University

Hopple JS Jr, Vilgalys R 1999 Phylogenetic relationships in the mushroom genus Coprinus and dark spored allies based on sequence data from the nuclear gene coding for the large ribosomal subunit RNA: divergent domains, outgroups, and monophyly. Mol Phylogenet

Jwanny E W, Rashad M M, Abdu H M. 1995 Solid-state fermentation of agricultural wastes into food through pleurotus cultivation. Applied Biochemistry \& Biotechnology, 50(1): 71-78

Kobayasi, Y. 1981 The genus Auricularia. Bulletin of the National Science Museum (Tokyo), 7(2): 41-67

Li L. J. 1984 Two new species of Auricularia, Mycosystema, 4(3): 149-154

Lowy, B. 1952 The genus Auricularia. Mycologia, 44(5): 656-692

Lu T, Bau T, Ohga S. 2017 Physiological study of the wild edible mushroom leucocalocybe mongolica. Journal Faculty of Agriculture Kyushu University, 62(1): 1-8
Lu T, Bau Tolgor. 2013 Biological characteristics and cultivation of fruit body of wild medicinal mushroom Perenniporia fraxinea. Acta Ecologica Sinica, 33(17): 5194-5200

Ma J, Qiao Z, Xiang X. 2011 Optimisation of extraction procedure for black fungus polysaccharides and effect of the polysaccharides on blood lipid and myocardium antioxidant enzymes activities Carbohydrate Polymers, 84(3): 1061-1068

Malysheva, V. F., Bulakh, E. M. 2014 Contribution to the study of the genus Auricularia (Auriculariales, Basidiomycota) in Russia. Novosti Sistematiki Nizshikh Rastenii, 48: 164-180

Matheny P B. 2005 Improving phylogenetic inference of mushrooms with RPB1 and RPB2 nucleotide sequences (Inocybe; Agaricales). Molecular phylogenetics and evolution, 35(1): 1-20

Matheny, P. B., Wang, Z., Binder, M., Curtis, J. M., Lim, Y. W. Nilsson, R. H., ... \& Langer, E. 2007 Contributions of rpb2 and tef1 to the phylogeny of mushrooms and allies (Basidiomycota, Fungi). Molecular phylogenetics and evolution, 43(2): 430-451

Posada, D., \& Crandall, K. A. 1998 Modeltest: testing the model of DNA substitution. Bioinformatics, 14(9): 817-818

Rizal L M, Hyde K D, Chukeatirote E, et al. 2015 First Successful Cultivation of the Edible Mushroom Macrolepiota dolichaula in Thailand Chiang Mai. Journal of Science, $\mathbf{4 3}(5)$

Ronquist, F., \& Huelsenbeck, J. P. 2003 MrBayes 3: Bayesian phylogenetic inference under mixed models. Bioinformatics, 19(12): 1572-1574

Shim S M, Yun H O, Lee K R, et al. 2005 The Characteristics of Cultural Conditions for the Mycelial Growth of Macrolepiota procera. Mycobiology, 33(1): 15

Wang J, Yao F J, Wang X E, et al. 2014 Study on Cultivation Characteristics of Four Wild Species of Auricularia Bull. ex Mérat. Edible Fungi of China

Wang jing. 2013 Study on the Mrophological Development and Dosmentication of Auricularia polytricha. Jilin agricultural university

White, T. J., Bruns, T., Lee, S. J. W. T., \& Taylor, J. W. 1990 Amplification and direct sequencing of fungal ribosomal RNA genes for phylogenetics. PCR protocols: a guide to methods and applications, 18(1): 315-322

Wu F. 2016 Taxonomy and phylogeny of Auricularia (Auriculariales, Basidiomycota). Doctoral Dissertation of Beijing Forestry University

Wu Rengao. $2010 \quad$ Sereening Excellent Wild Auricularia Auricula Strain and Investigation into Its Physiologieal ProPerties. Graduate Sehool of Chinese Aeademy of Agricultural Sciences

Wu, F., Yuan, Y., Liu, H. G., Dai, Y. C. 2014 Auricularia (Auriculariales, Basidiomycota): a review of recentresearch progress. Mycosystema 33(2): 198-207

Yan, J. Q. and T. Bau, 2017 New and newly recorded species of Psathyrella (Psathyrellaceae, Agaricales) from northeast China. Phytotaxa, 321(1): 139

Yan, P. S., Luo, X. C., Zhou, Q. 1999 RFLP study on specific amplified fragment of rDNA from Auricularia. Mycosystema. 18(2): 206-213

Yang, X. b., Song, H., Liu, Q., Li, S. N., Pan, Z. T. 2010 Application Progress of DNA Molecular Markers in Auricularia. Journal of Fungal Research, 8(3): 181-186

Zhu Y, Du S, Che J. 2011 Effect of inorgainic salts and growth factors on the mycelial growth of Morchella esculenta[J]. Journal of Northwest A \& F University, 39(4): 211-215 